\title{
Histological comparison between preoperative and surgical specimens of non-small cell lung cancer for distinguishing between "squamous" and "non-squamous" cell carcinoma
}

Tomoko Yamagishi $^{1+}$, Katsuhiko Shimizu ${ }^{2 *+}$, Nobuaki Ochi ${ }^{1 \dagger}$, Hiromichi Yamane ${ }^{1+}$, Isao Irei $^{3+}$, Yoshito Sadahira ${ }^{3+}$, Nagio Takigawa ${ }^{1 \dagger}$, Mikio Oka ${ }^{4 \dagger}$ and Masao Nakata $^{2+}$

\begin{abstract}
Background: Non-small cell lung cancers (NSCLCs) are frequently heterogeneous and in approximately $70 \%$ of cases, NSCLCs are diagnosed and staged by small biopsies or cytology rather than by examination of surgically resected specimens. Thus, in most patients, the diagnosis is established based on examination of preoperative specimens alone. Recently, classification of NSCLC into pathologic subtypes has been shown to be important for selecting the appropriate systemic therapy, from both the point of view of treatment efficacy and prevention of toxicity.

Methods: We retrospectively reviewed the data of 225 patients to compare the preoperative classification of the NSCLC subtype on biopsy specimens with the postoperative classification based on examination of the resected specimens, in order to compare the accuracy of the two for the diagnosis of various histological subtypes of NSCLC.

Results: In 169 of the 225 (75.1\%) patients, the preoperative diagnosis was definite malignancy. Histologically, the final pathologic diagnosis made from the surgical specimens was adenocarcinoma (ADC) in 169 patients, and in $75.5 \%$ of these cases, the diagnosis was concordant with the preoperative diagnosis. Among the patients who had squamous cell carcinoma (SQC) in the preoperative specimens, the diagnosis was concordant with the preoperative diagnosis in 65.7\% of cases. Misclassified preoperative biopsies included an even number of SQCs and ADCs, with all the misclassified biopsies being ADCs morphologically mimicking SQC due to solid growth. Significantly higher specificity, negative predictive value and accuracy were observed for the diagnosis of SQC.

Conclusions: Our study suggested that the concordance rates for diagnosis of the NSCLC subtypes, especially the "squamous" or "non-squamous" histologies, between preoperative and surgical specimens were satisfactory, as compared with previous reports. Therefore, pretreatment diagnosis of lung cancer using small samples is reasonable for selecting the optimal treatment. However, in order not to lose the opportunity for selecting an effective treatment, we should be aware that the diagnosis in preoperative small samples might be different from that based on examination of the surgical specimens.
\end{abstract}

Virtual Slides: The virtual slide(s) for this article can be found here: http://www.diagnosticpathology.diagnomx.eu/vs/ 2032698427120488

\footnotetext{
* Correspondence: kshimizu@med.kawasaki-m.ac.jp

${ }^{\dagger}$ Equal contributors

${ }^{2}$ Department of General Thoracic Surgery, Kawasaki Medical School, 577

Matsushima, Kurashiki, Okayama 701-0192, Japan

Full list of author information is available at the end of the article
} 


\section{Background}

Lung cancer is the leading cause of cancer and mortality from cancer worldwide [1], with 5-year survival rates of $<15 \%$ across all stages of the disease [2]. Historically, lung cancer is divided into two morphologic types: small cell lung cancer and non-small-cell lung cancer (NSCLC), with NSCLC accounting for approximately $80 \%$ to $85 \%$ of all histological types of NSCLC [3].

The International Association for the Study of Lung Cancer, the American Thoracic Society, and the European Respiratory Society recently proposed the classification of NSCLC based on examination of small biopsy and/or cytology specimens into six main subtypes: adenocarcinoma (ADC), squamous cell carcinoma (SQC), NSCLC not otherwise specified (NSCLC-NOS), NSCLC with neuroendocrine morphology, NSCLC with squamous and adenocarcinoma patterns, and poorly differentiated NSCLC with spindle and/or giant cell carcinoma [4]. NSCLCs are frequently heterogeneous and approximately $70 \%$ of NSCLCs are diagnosed and staged by examination of small biopsy or cytology specimens rather than by examination of surgically resected specimens [5]; thus, in most patients, the diagnosis is based on examination of preoperative specimens alone. Until now, histological subtyping of NSCLC was not considered to be clinically or therapeutically important, because of the lack of existence of differential treatment options for the various subtypes of NSCLC. However, there is now clear evidence to suggest that the classification of NSCLC into pathologic subtypes is important for the selection of appropriate systemic therapy, from both the point of view of treatment efficacy and prevention of toxicity [6,7]. For example, large phase III clinical trials have demonstrated that ADC is a strong predictive factor for improved outcome following treatment with the combination of pemetrexed with cisplatin compared with SQC [8]. In addition, the presence of common activating mutations in the tyrosine kinase domain of the epidermal growth factor receptor (EGFR) gene (exon 19 deletion and exon 21 L858R mutation) confers strong sensitivity to gefitinib and erlotinib, which are selective tyrosine kinase inhibitors of EGFR [9,10]. These EGFR mutations are more commonly encountered in ADCs [11]. Furthermore, the use of vascular endothelial growth factor (VEGF) inhibitors (eg, bevacizumab) has been demonstrated to be associated with an increased risk of fatal pulmonary hemorrhage in patients with SQC [12]. The $A L K$ tyrosine inhibitor crizotinib was demonstrated to show marked antitumor activity in NSCLC patients with $E M L 4-A L K$ translocation, observed in approximately 3 to $4 \%$ of patients with ADC [13]. Thus, a molecular testing guideline has been proposed [14].

If pathological findings are missed, especially when differentiating between "squamous" and "non-squamous" histology, determination of the appropriate treatment is difficult. The aim of this study was to compare the
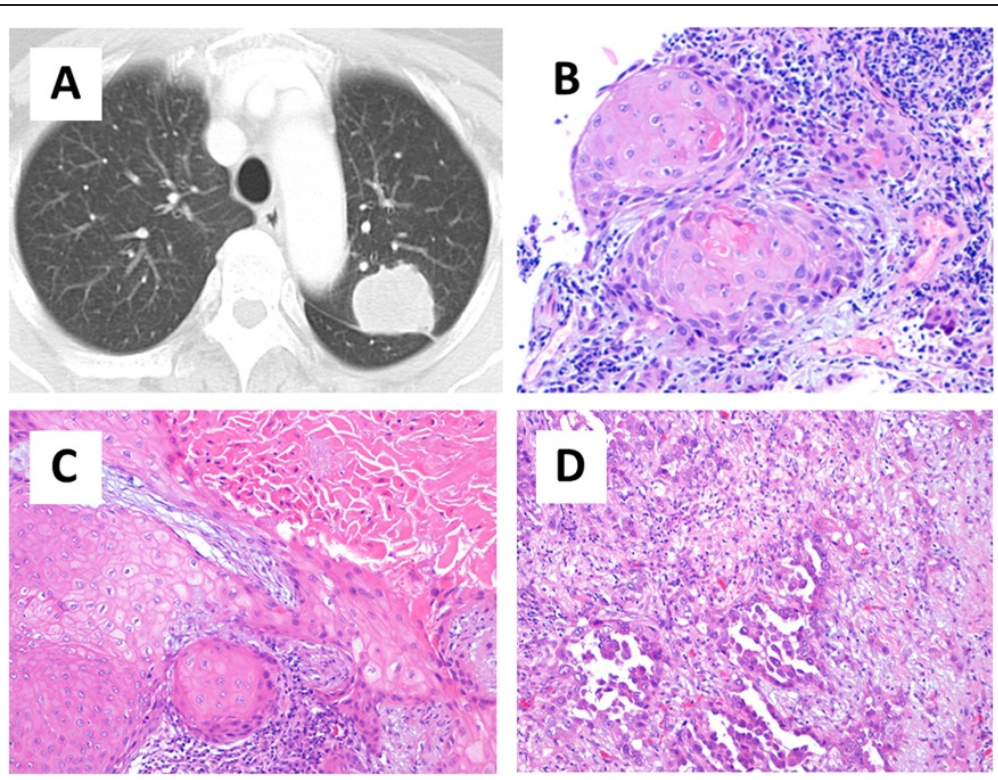

Figure $1 \mathrm{~A}$ case with discordant diagnosis of the histological subtype between preoperative and surgical specimens. (A) Computed tomographic image showing a mass lesion measuring $4 \mathrm{~cm}$ in diameter in the left upper lobe. (B) Computed tomography-guided fine needle biopsy was performed. Pathological findings of the biopsy specimen showed keratinized cells, suggestive of squamous cell carcinoma (H.E. stain, $\times 100)$. (C-D) Surgically resected specimen showing both a squamous and glandular component, suggesting the postoperative diagnosis of adenosquamous carcinoma (H.E. stain, $\times 100)$. 
preoperative classification of NSCLC based on biopsy specimens with the postoperative classification made on the basis of examination of resected specimens, and to examine how often accuracy about each histological subtypes of NSCLC.

\section{Methods}

\section{Patient population}

Between April 2004 and June 2011, 442 patients underwent surgical resection for lung cancer at Kawasaki Medical School Hospital, Kurashiki, Japan. We retrospectively reviewed the data of a consecutive series of $225(50.9 \%)$ patients in whom preoperative diagnosis was made by transbronchial biopsy (TBB) or computed tomography-guided fine needle biopsy (CTNB). For each patient, the clinical information at diagnosis was collected from the medical records. This study was conducted with the approval of the institutional Ethics Committee of Kawasaki Medical School (No.887).

Transbronchial biopsy and computed tomography-guided fine needle biopsy procedures

While TBB is commonly performed in the diagnostic workup of pulmonary peripheral nodules, CTNB is usually performed either when the tumor is not detected bronchoscopically or when it is thought unlikely to be accessible by bronchoscopy. Flexible bronchoscopy is conducted by experienced bronchoscopists, while CTNB is performed by interventional radiologists, with standard techniques for both. All aspirated materials and biopsy specimens were fixed in formalin and embedded in paraffin, and sections are routinely stained with hematoxylin and eosin (H\&E). Cytological examinations of sputum, aspirated material and bronchial brushings, and washing were not included in the diagnostic workup in this study, because the aim of the study was histological comparison between preoperative biopsy specimens and surgically resected specimens.

The results of the examination of the small diagnostic specimens were classified as no malignancy, suspected malignancy or definite malignancy. Furthermore, definite malignancy of NSCLC was classified into ADC, SQC, NSCLC or other histological subtypes (others). If there is no clear ADC or SQC morphology, the tumor can be further classified based on immunohistochemocal stains (IHC) and mucin (periodic acid Schiff) stains. If the stains all favor ADC: positive ADC markers (i.e., TTF-1 and/or mucin positive) with negative SQC markers, then the tumor is classified as ADC. If SQC markers (i.e., p63) are positive with negative $\mathrm{ADC}$ markers, the tumor is classified as SQC. If the ADC and SQC markers are both strongly positive and negative, the tumor is classified as NSCLC-NOS and others.
Table 1 Patient characteristics $(n=225)$

\begin{tabular}{lcc}
\hline Variable & Number & $\%$ \\
\hline Age, mean \pm SD & $69.0 \pm 10.2$ & \\
Sex & 159 & 70.7 \\
$\quad$ Male & 66 & 29.3 \\
Female & & \\
Histology & 139 & 61.5 \\
Adenocarcinoma & 67 & 30.1 \\
Squamous cell & 10 & 4.4 \\
NSCLC-NOS & 5 & 2.2 \\
Pleomorphic & 4 & 1.8 \\
Adenosquamous & & \\
Pathological stage & 78 & 34.5 \\
IA & 53 & 23.9 \\
IB & 23 & 10.2 \\
IIA & 24 & 10.6 \\
IIB & 36 & 15.9 \\
IIIA & 11 & 4.9 \\
IIIB/IV & & \\
\hline Abbreviations: NSCLCNOSNon-small-cell lung carcinoma not otherwise specified.
\end{tabular}

\section{Statistical analysis}

Sensitivity, specificity, positive predictive value (PPV), negative predictive value (NPV), and accuracy were calculated according to the standard definitions for the diagnosis of lung cancer and malignancy. Continuous variables were analyzed by the Student's $t$-test, and the results were expressed as mean \pm standard deviation (SD). Dichotomous variables were analyzed by the Fisher's exact test or the $\chi^{2}$ test, as appropriate. Discontinuous variables were coded as dummy variables. Two-sided p-values of less than 0.05 were considered to be statistically significant. All analyses were performed using the SPSS software (Version 17.0; SPSS Incorporation, Chicago, IL).

Table 2 Comparison between preoperative specimens and surgical diagnosis

\begin{tabular}{|c|c|c|c|c|c|c|}
\hline \multirow{2}{*}{$\begin{array}{l}\text { Preoperative } \\
\text { diagnosis }\end{array}$} & \multicolumn{6}{|c|}{ Postoperative diagnosis } \\
\hline & ADC & SQC & NSCLC-NOS & ASC & PLE & Total \\
\hline \multicolumn{7}{|l|}{ Malignant } \\
\hline$A D C$ & 105 & 3 & 2 & 3 & 2 & 115 \\
\hline SQC & & 44 & & 1 & & 45 \\
\hline NSCLC-NOS & 2 & 1 & 4 & & & 7 \\
\hline PLE & & & & & 2 & 2 \\
\hline Suspicious of NSCLC & 5 & 7 & 1 & & & 13 \\
\hline Not malignant & 27 & 12 & 3 & & 1 & 43 \\
\hline Total & 139 & 67 & 10 & 4 & 5 & 225 \\
\hline
\end{tabular}

Abbreviations: $A D C$ adenocarcinoma, SQC squamous cell carcinoma NSCLC-NOS non-small-cell lung cancer not otherwise specified, ASC adenosquamous carcinoma, PLE pleomorphic carcinoma. 
Table 3 Diagnostic value of preoperative diagnosis between adenocarcinoma and squamous cell carcinoma

\begin{tabular}{|c|c|c|c|c|c|}
\hline & $\begin{array}{c}\text { Sensitivity } \\
\text { (\%) }\end{array}$ & $\begin{array}{c}\text { Specificity } \\
\text { (\%) }\end{array}$ & $\begin{array}{l}\text { PPV } \\
(\%)\end{array}$ & $\begin{array}{l}\text { NPV } \\
(\%)\end{array}$ & $\begin{array}{c}\text { Accuracy } \\
\text { (\%) }\end{array}$ \\
\hline \multirow[t]{2}{*}{ Lung cancer } & 75.1 & - & 100 & 100 & 75.1 \\
\hline & $(169 / 225)$ & & $(169 / 169)$ & $(56 / 56)$ & $(169 / 225)$ \\
\hline \multirow[t]{2}{*}{$A D C$} & 75.5 & 88.3 & 91.0 & 69.0 & 80.4 \\
\hline & $(105 / 139)$ & $(76 / 86)$ & $(105 / 115)$ & $(76 / 110)$ & $(181 / 225)$ \\
\hline \multirow[t]{2}{*}{ SQC } & 65.6 & 99.3 & 97.7 & 87.2 & 89.3 \\
\hline & $(44 / 67)$ & $(157 / 158)$ & $(44 / 45)$ & $(157 / 180)$ & $(201 / 225)$ \\
\hline p-value (ADC vs. SQC) & 0.138 & $<0.001$ & 0.184 & $<0.001$ & 0.012 \\
\hline
\end{tabular}

Abbreviations: PPV Positive predictive value, NPV Negative predictive value, ADC adenocarcinoma, SQC squamous cell carcinoma.

\section{Results}

\section{Case report}

A 74-year-old woman who was a never-smoker was referred to our hospital because of hoarseness. Computed tomography showed a solid mass approximately $4 \mathrm{~cm}$ in diameter in the left upper lobe associated with mediastinal lymphadenopathy (Figure 1A). CTNB was carried out, and biopsy examination confirmed a well-keratinized tumor without obvious glandular features or cytoplasmic mucin (Figure 1B). The patient was diagnosed as having SQC of the lung, stage IIIA (T2aN2M0). Left upper lobectomy with mediastinal lymph node dissection was performed. Both ADC and SQC components were observed in the pathological specimen, suggesting the postoperative diagnosis of adenosquamous carcinoma (Figure $1 C \& D$ ). One year later, recurrence was found in the form of mediastinal lymphadenopathy. We performed a molecular analysis of the surgical specimens, which revealed an EGFR gene mutation, and treatment with oral gefitinib was initiated. The patient would have lost the opportunity to receive gefitinib treatment if had just been diagnosed as having inoperable advanced NSCLC, because the molecular testing guideline does not recommend EGFR mutation analysis in patients with SQC [14].

\section{Patient characteristics}

A total of 225 patients (159 men and 66 female; mean age, $69.0 \pm 10.2$ years) were enrolled in this study. The pathological stage and histological type on the final pathological examination are shown in Table 1 . The most frequent histological type was ADC; 139 (61.5\%) had ADC, 67 (30.1\%) had SQC, 10 (4.4\%) had large cell carcinoma, and 9 (4.0\%) had others (other subtypes). The patients were classified according to the histopathological stage as follows: 131 patients had stage I, 47 had stage II, and 47 had stage III or IV disease. Most stage III and IV patients were recognized during and after surgery due to mediastinal lymph node metastasis (cN0pN2) and pleural dissemination (cM0-pM1a). A few stage III patients were performed resection due to single mediastinal lymph node metastasis.

\section{Sensitivity of preoperative diagnosis for the detection of NSCLC}

The preoperative diagnosis was compared with the final pathological findings (Table 2). In 169 of the 225 (75.1\%) patients, the preoperative diagnoses were definite malignancy (115 ADC, 45 SQC, 2 large cell carcinoma, 2 pleomorphic carcinoma, and 5 NSCLC). In 56 of the 225 (24.9\%) patients, the preoperative specimens showed suspected or no malignancy: while NSCLC was suspected preoperatively in 13 of these patients, no malignancy was suspected in 43 patients. The overall sensitivity for the detection of lung cancer was $75.1 \%$.

Histologically, the final pathological examination of the surgical specimens revealed ADC in 139 patients, of whom in 105 (75.5\%) patients, the diagnosis was concordant with the preoperative diagnosis. Of the remaining 34

Table 4 Comparison of H\&E stain vs IHC for subtyping NSCLC

\begin{tabular}{|c|c|c|c|c|c|c|c|c|}
\hline \multirow{3}{*}{$\begin{array}{l}\text { Postoperative } \\
\text { diagnosis }\end{array}$} & \multicolumn{8}{|c|}{ Preoperative diagnosis } \\
\hline & \multicolumn{4}{|c|}{ H\&E diagnosis } & \multicolumn{4}{|c|}{ IHC predicted phenotype } \\
\hline & $A D C$ & SQC & Unclassified & Total & $A D C$ & SQC & Unclassified & Total \\
\hline$\overline{\mathrm{ADC}}$ & 79 & & 28 & 107 & 26 & & & 26 \\
\hline SQC & 2 & 40 & 6 & 48 & 1 & 3 & & 4 \\
\hline Unclassified & 5 & 2 & 7 & 14 & 2 & & 3 & 5 \\
\hline Total & 86 & 42 & 41 & 169 & 29 & 3 & 3 & 35 \\
\hline
\end{tabular}

Abbreviations: ADC adenocarcinoma, SQC squamous cell carcinoma, NSCLC-NOS non-small-cell lung cancer not otherwise specified, PLE pleomorphic carcinoma, $H \& E$ hematoxylin and eosin, IHC immunohistochemistry. 


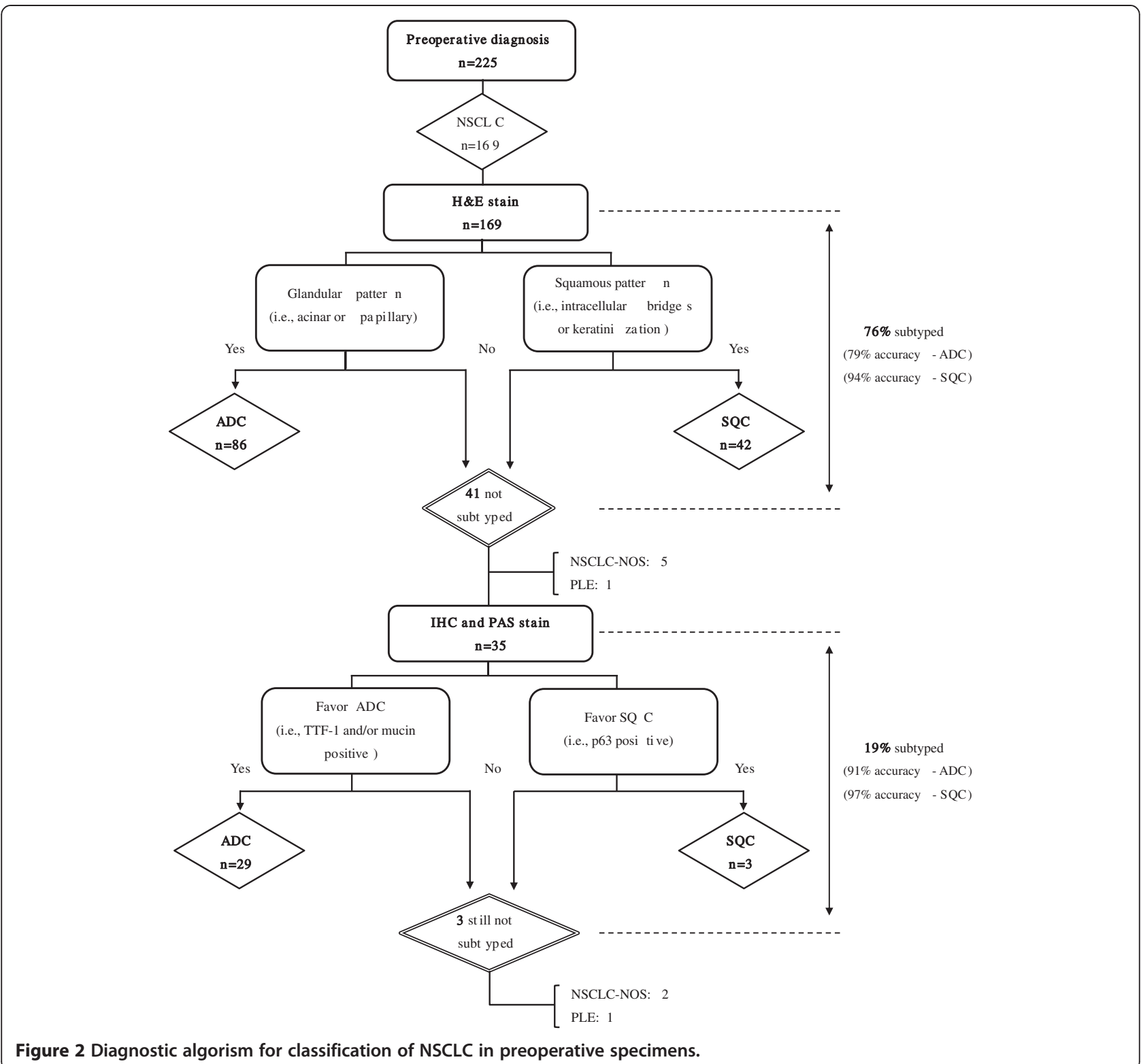

patients, 2 patients had NSCLC, 5 patients had suspected NSCLC, and 27 patients had no malignancy. In all, 67 patients had SQC of the lung on the preoperative specimens, and in 44 (65.7\%) of these patients, the diagnosis was concordant with the preoperative diagnosis. Among the 23 of the remaining $67(34.3 \%)$ with a discordant diagnosis, 3 patients had ADC, 1 patient had NSCLC, 7 patients had suspected NSCLC and 12 patients had no evidence of malignancy. Misclassified preoperative biopsies included an even number of SQCs and ADCs $(n=3)$, whereas all of the misclassified biopsies were ADC, morphologically mimicking SQC due to the solid growth.

We compared the sensitivity, specificity, predictive values and accuracy for the diagnosis of ADC and SQC
(Table 3). Significantly higher specificity, NPV and accuracy were observed for SQC $(\mathrm{p}<0.05)$.

\section{Comparison of H\&E stain vs. IHC for subtyping NSCLC}

For the comparison of H\&E stain vs IHC, 169 patients were included, all of whom underwent H\&E stain. Among them, IHC was performed on 35 (21\%) patients (Table 4). As summarized in Figure 2, 128 of 169 patients (76\%) were specifically subtyped on the H\&E stain as either ADC or SQC. 41 (24\%) patients were not subtyped on the H\&E stain sections. IHC could successfully subtype NSCLC in 32 of 35 cases (29 ADC, 3 SQC). The remaining three cases were not still subtyped (2 NSCLC-NOS, 1 PLE). However, by combining the results of the two methods, 
Table 5 Comparison of TBB vs. CTNB for sensitivity/concordance rate

\begin{tabular}{|c|c|c|c|c|c|c|c|}
\hline & & Histological diagnosis & & & & & \\
\hline & Lung cancer & Suspicious of malignancy & No malignancy & Sensitivity & p-value & Concordance & $\mathrm{p}$-value \\
\hline TBB & 140 & 13 & 37 & $73.2(140 / 190)$ & 0.249 & $66.8(127 / 190)$ & 0.594 \\
\hline CTNB & 29 & 0 & 6 & $82.9(29 / 35)$ & & $71.4(25 / 35)$ & \\
\hline Total & 169 & 13 & 43 & $75.0(169 / 225)$ & & $67.6(152 / 225)$ & \\
\hline
\end{tabular}

Abbreviations: TBB Transbronchial biopsy, CTNB Computed tomography-guided fine needle biopsy.

the number of patients with not subtyped diagnoses was reduced to $9(5 \%)$ patients. The accuracy of both morphologic differentiation and IHC based predictive subtype is $<100 \%$ (Figure 2 ).

\section{Comparison of TBB vs. CTNB for the sensitivity or concordance of lung cancer diagnosis}

Among the 225 patient studied, TBB was performed in 190 patients. Of these, 140 (73.7\%) were diagnosed as having definite lung cancer, 13 (6.8\%) were suspected as having malignancy, and 37 (19.5\%) were diagnosed as having no malignancy. CTNB was performed in 35 patients. Of these, $29(82.9 \%)$ and $6(17.1 \%)$ cases were diagnosed as having lung cancer and no malignancy, respectively. Thus, there was no significant difference in the level of diagnostic certainty between TBB and CTNB (Table 5).

\section{Comparison of the sensitivity or concordance rate of the histological type between preoperative and surgical} specimens in relation to the tumor size

The results of detection of lung cancer were correlated with the tumor size. The overall sensitivity and concordance rate of histological type between preoperative biopsies and surgical specimens were $75.1 \%(169 / 225)$ and $67.6 \%(152 / 225)$. The sensitivity rate was correlated with the tumor size. The diagnostic sensitivity of lesions larger than $2.1 \mathrm{~cm}$ in diameter was significantly better than that of lesions less than $2 \mathrm{~cm}$ in diameter $(\mathrm{p}=0.001$, Table 6). However, concordance rate was not correlated with the tumor sizes.

\section{Discussion}

We assessed the accuracy of diagnosis of the histological type of lung cancer between preoperative and surgical specimens. The reported accuracy for bronchoscopic biopsy as compared to histopathology of resected or autopsy specimens for differentiating among histological subtypes of lung cancer is in the range of $62 \%$ to $97.5 \%$ [15-19]. In our study, the concordance rates for diagnosis of the NSCLC subtypes between preoperative biopsies and histopathology of surgical specimens was $66.8 \%$ $(127 / 190)$, which seemed to be slightly low as compared to previous reports; however, many studies excluded tumors that were confirmed as not being malignant: in our study, 50 (26.3\%) of 190 patients were diagnosed as not having malignant lesions before excision. After patients without malignancies as determined in preoperative specimens were excluded, the concordance rate was $90.7 \%(127 / 140)$. We found a better accuracy for the diagnosis of SQC than for that of ADC (89.3\% vs. $80.4 \%$, $\mathrm{p}=0.012$ ), which was also in agreement with previous studies $[13,20]$. On the other hand, the sensitivity for ADC was slightly better than that for SQC (75.7\% vs. $65.6 \%, \mathrm{p}=0.138)$, indicating that ADC seems to have little oversight by preoperative specimens.

IHC studies are usually required if obvious morphological features of squamous or glandular differentiation are not identified. Similar to the findings of this study, prior studies found that $\sim 75 \%$ of bronchial NSCLC samples may be subtyped using morphology alone, and 93\% of all NSCLC cases may be subtyped when combined immunostaining [21]. Other studies also demonstrated that only a low population (6\%) of cases remained without a probable subtype after morphologic examination and IHC [22]. The low not-typed rate in these studies suggests that we should perform IHC as a routine utilization for subtyping of difficult cases.

Several factors affect the diagnostic accuracy. The frequency of diagnostic errors induced by some of these factors, including the biopsy size and degree of differentiation has been described [20]. In our study, the tumor size was correlated with the sensitivity and concordance rate: the larger the diameter, the greater the sensitivity and cell type agreement.

Table 6 Comparison between tumor size and sensitivity/concordance rate

\begin{tabular}{|c|c|c|c|c|c|c|c|}
\hline & & Histological diagnosis & & & & & \\
\hline & Lung cancer & Suspicious of malignancy & No malignancy & Sensitivity & p-value & Concordance & $\mathrm{p}$-value \\
\hline$<=2 \mathrm{~cm}$ & 30 & 0 & 19 & $61.2(30 / 49)$ & 0.011 & $57.1(28 / 49)$ & 0.078 \\
\hline$>2 \mathrm{~cm}$ & 139 & 13 & 24 & $78.9(139 / 176)$ & & $70.4(124 / 176)$ & \\
\hline Total & 169 & 13 & 43 & $75.0(169 / 225)$ & & $67.6(152 / 225)$ & \\
\hline
\end{tabular}


Until date, therapeutic decisions are heavily dependent on the histological subtype of lung cancer (SQC vs. non$\mathrm{SQC}$ ) and its molecular characteristics (e.g., EGFR mutation and ALK rearrangement states). Furthermore, many previous studies showed the expression and functions of proteins and genes in lung cancer, and it may be significantly related to tumor progression and metastasis [23-26].

Both EGFR mutation and $A L K$ rearrangements are almost exclusively seen in ADC. According to multiple large phase III crinical trials [11,27-29], the new classification recommends that all patients with advanced lung $\mathrm{ADC}$ be tested for EGFR mutation, as EGFR tyrosine kinase inhibitors can be used as first-line chemotherapy for patients with EGFR mutations. Crizotinib has been approved by the US Food and Drug Administration (FDA) for advanced ADC with ALK rearrangements [30]. Therefore, testing for EGFR mutations and ALK rearrangements in patients with advanced ADC is no longer only a research tool, and should be performed in clinical practice. On the other hand, several molecular targets such as FGFR1 amplification and DDR2 mutation have been discovered in SQC [31,32]. Target therapies that might be beneficial in this selected subpopulation have never been reported. These results indicate that misdiagnosis of ADC as SQC in preoperative specimens should be avoided so as to prevent the loss of opportunity to select beneficial molecular-targeted therapy for these patients in clinical practice. Although such a result was not seen, there were three $(1.3 \%)$ misclassifications between ADC and SQC in the preoperative specimens, and in all, SQC was diagnosed as ADC. Fortunately, there was only a lone patient who might have lost the opportunity to receive EGFR-TKI therapy by missed diagnosis $(0.44 \%$, shown as case report).

Our retrospective study had some limitations. First, only half of the patients who underwent surgery received preoperative diagnosis by TBB or CTNB. Second, there may be variability between intra- and inter- pathologist in lung cancer diagnosis. Because a smaller amount of tissue is obtained, the diagnostic assessment might be more difficult and more inconsistencie in the diagnosis of pathologists might occur. In such cases, multidisciplinary approach and expert consultation are recommended [33].

\section{Conclusions}

In conclusion, our study suggested that the concordance rate for the diagnosis of NSCLC subtypes, especially "squamous" or "non-squamous" histology, between preoperative and surgical specimens was satisfactory as compared with other reports. Pretreatment diagnosis of lung cancer using small samples is reasonable for selection of the optimal treatment. However, our case report presented above serves to emphasize the need to be aware that diagnosis based on preoperative small samples might be different from that made from surgical specimens, so as to not lose the opportunity for effective treatment.

\section{Consent}

Written informed consent was obtained from the patient for the publication of this report and any accompanying images.

\section{Competing interests}

The authors declare that they have no competing interests.

\section{Authors' contributions}

TY and KS designed and wrote the paper. NO, HY, NT and MO participated in the design of the study and reviewed the literature. KS and MN performed surgery. All authors read and approved the final manuscript.

\section{Author details}

'Department of General Internal Medicine 4, Kawasaki Medical School, 2-1-80, Nakasange, Kita-ku, Okayama 700-8505, Japan. ²Department of General Thoracic Surgery, Kawasaki Medical School, 577 Matsushima, Kurashiki, Okayama 701-0192, Japan. ${ }^{3}$ Department of Pathology, Kawasaki Medical School, 577 Matsushima, Kurashiki, Okayama 701-0192, Japan. ${ }^{4}$ Department of Respiratory Medicine, Kawasaki Medical School, 577 Matsushima, Kurashiki, Okayama 701-0192, Japan.

Received: 5 February 2014 Accepted: 15 May 2014

Published: 29 May 2014

\section{References}

1. Jemal A, Bray F, Center MM, Ferlay J, Ward E, Forman D: Global cancer statistics. CA Cancer J Clin 2011, 61:69-90.

2. Crino L, Weder W, Van Meerbeeck J, Felip E: Early stage and locally advanced (non-metastatic) non-small-cell lung cancer. ESMO clinical practice guidelines for diagnosis, treatment and follow-up. Ann Oncol 2010, 21:103-1.

3. Itaya T, Yamaoto N, Ando M, Ebisawa M, Nakamura Y, Murakami H, Asai G, Endo M, Takahashi T: Influence of histological type, smoking history and chemotherapy on survival after first-line therapy in patients with advanced non-small cell lung cancer. Cancer Sci 2007, 98:226-230.

4. Travis WD, Brambilla E, Noguchi M, Nicholson AG, Geisinger KR, Yatabe $Y$, Beer DG, Powell CA, Riely GJ, Van Schil PE, Garg K, Austin JH, Asamura H, Rusch WW, Hirsch FR, Scagliotti G, Mitsudomi T, Huber RM, Ishikawa Y, Jett J, Sanchez-Cespedes M, Sculier JP, Takahashi T, Tsuboi M, Vansteenkiste J, Wistuba I, Yang PC, Aberle D, Brambilla C, Flieder D, et al: International association for the study of lung Cancer/American thoracic Society/ European respiratory society international multidisciplinary classification of lung adenocarcinoma. J Thorac Oncol 2011, 6:244-285.

5. Shah PL, Singh S, Bower M, Livni N, Padley S, Nicholson AG: The role of transbronchial fine needle aspiration in an integrated care pathway for the assessment of patients with suspected lung cancer. J Thorac Oncol 2006, 1:324-327.

6. Einhorn LH: First-line chemotherapy for non-small-cell lung cancer: is there a superior regimen based on histology? J Clin Oncol 2008, 20:3485-3486

7. Stinchcombe TE, Grilley-Olson JE, Socinski MA: If histology matters. J Clin Oncol 2010, 28:1810-1812.

8. Scagliotti GV, Parikh P, Von Pawel J, Biesma B, Vansteenkiste J, Manegold C, Serwatowski P, Gatzemeier U, Digumarti R, Zukin M, Lee JS, Mellemgaard A, Park K, Patil S, Rolski J, Goksel T, De Marinis F, Simms L, Sugarman KP, Gandara D: Phase III study comparing cisplatin plus gemcitabine with cisplatin plus pemetrexed in chemotherapy-naïve patients with advanced-stage non-small-cell lung cancer. J Clin Oncol 2008, 26:3543-3551.

9. Lynch TJ, Bell DW, Sordella R, Gurubhagavatula S, Okimoto RA, Brannigan BW, Harris PL, Haserlat SM, Supko JG, Haluska FG, Louis DN, Christiani DC, Settleman J, Haber DA: Activating mutations in the epidermal growth factor receptor underlying responsiveness of non-small-cell lung cancer to gefitinib. N Engl J Med 2004, 350:2129-2139. 
10. Paez JG, Jänne PA, Lee JC, Tracy S, Greulich H, Gabriel S, Herman P, Kaye FJ, Lindeman N, Boggon TJ, Naoki K, Sasaki H, Fujii Y, Eck MJ, Sellers WR, Johnson BE, Meyerson M: EGFR mutations in lung cancer: correlation with clinical response to gefitinib therapy. Science 2004, 304:1497-1500.

11. Mok TS, Wu YL, Thongprasert S, Yang CH, Chu DT, Saijo N, Sunpaweravong $P$, Han B, Margono B, Ichinose $Y$, Nishiwaki Y, Ohe $Y$, Yang JJ,

Chewaskulyong B, Jiang H, Duffield EL, Watkins CL, Armour AA, Fukuoka M: Gefitinib or carboplatin-paclitaxel in pulmonary adenocarcinoma. N Engl J Med 2009, 361:947-957.

12. Johnson DH, Fehrenbacher L, Novotny WF, Herbst RS, Nemunaitis JJ, Jablons DM, Langer CJ, DeVore RF 3rd, Gaudreault J, Damico LA, Holmgren E, Kabbinavar F: Randomized phase II trial comparing bevacizumab plus carboplatin and paclitaxel with carboplatin and paclitaxel alone in previously untreated locally advanced or metastatic non-small-cell lung cancer. J Clin Oncol 2004, 22:2184-2191.

13. Edwards SL, Roberts C, McKean ME, Cockburn JS, Jeffrey RR, Kerr KM: Preoperative histological classification of primary lung cancer: accuracy of diagnosis and use of the non-small cell category. J Clin Pathol 2000, 53:537-540.

14. Lindeman NI, Cagle PT, Beasley MB, Chitale DA, Dacic S, Giaccone G, Jenkins RB, Kwiatkowski DJ, Saldivar JS, Squire J, Thunnissen E, Ladanyi M: Molecular testing guideline for selection of lung cancer patients for EGFR and ALK tyrosine kinase inhibitors: guideline from the College of American Pathologists, international association for the study of lung cancer, and association for molecular pathology. J Thorac Oncol 2013, 8:823-859.

15. Cataluna JJ, Perpina M, Greses JV, Calvo V, Padilla JD, París F: Cell type accuracy of bronchial biopsy specimens in primary lung cancer. Chest 1996, 109:1199-1203.

16. Matsuda M, Horai T, Nakamura S, Nishio H, Sakuma T, Ikegami H, Tateishi R: Bronchial brushing and bronchial biopsy: comparison of diagnostic accuracy and cell typing reliability in lung cancer. Thorax 1986, 41:475-478

17. Rudd RM, Gellert AR, Boldy DA, Studdy PR, Pearson MC, Geddes DM: Bronchoscopic and percutaneous aspiration biopsy in the diagnosis of bronchial carcinoma cell type. Thorax 1982, 37:462-465.

18. Clee MD, Duguid HL, Sinclair DJ: Accuracy of morphological diagnosis of lung cancer in a department of respiratory medicine. J Clin Pathol 1982 35:414-419.

19. Payne CR, Hadfield JW, Stovin PG, Barker V, Heard BE, Stark JE: Diagnostic accuracy of cytology and biopsy in primary bronchial carcinoma. J Clin Pathol 1981, 34:773-778.

20. Arinç S, Saltürk C, Ertuğrul M, Sulu E, Tuncer L, Nergis S, Selvi U: Cell type agreement between bronchoscopic biopsy and thoracotomy specimens in primary lung cancer. Tuberk Toraks 2007, 55:378-382.

21. Loo PS, Thomas SC, Nicolson MC, Fyfe MN, Kerr KM: Subtyping of undifferentiated non-small cell carcinomas in bronchial biopsy specimens. J Thorac Oncol 2010, 5:442-447.

22. Sigel CS, Moreira AL, Travis WD, Zakowski MF, Thornton RH, Riely GJ, Rekhtman N: Subtyping of non-small cell lung carcinoma: a comparison of small biopsy and cytology specimens. J Thorac Oncol 2011, 6:1849-1856.

23. Shi $Y, W u H$, Zhang $M$, Ding L, Meng F, Fan X: Expression of the epithelial-mesenchymal transition-related proteins and their clinical significance in lung adenocarcinoma. Diagn Pathol 2013, 8:89. doi:10.1186/1746-1596-8-89.

24. Zheng S, Du Y, Chu H, Chen X, Li P, Wang Y, Ma Y, Wang H, Zang W, Zhang G, Zhao G: Analysis of MAT3 gene expression in NSCLC. Diagn Pathol 2013, 9(8):166. doi:10.

25. Xiong $Y$, Bai $Y$, Leong N, Laughlin TS, Rothberg PG, Xu H, Nong L, Zhao J, Dong Y, Li T: Immunohistochemical detection of mutations in the epidermal growth factor receptor gene in lung adenocarcinomas using mutation-specific antibodies. Diagn Pathol 2013, 8(1):27. Epub ahead of print.

26. Shilo K, Wu X, Sharma S, Welliver M, Duan W, Villalona-Calero M, Fukuoka J, Sif S, Baiocchi R, Hitchcock CL, Zhao W, Otterson GA: Cellular localization of protein arginine methyltransferase- 5 correlates with grade of lung tumors. Diagn Pathol 2013, 8:201. doi:10.1186/1746-1596-8-201.

27. Maemondo M, Inoue A, Kobayashi K, Sugawara S, Oizumi S, Isobe H, Gemma A, Harada M, Yoshizawa H, Kinoshita I, Fujita Y, Okinaga S, Hirano H, Yoshimori K, Harada T, Ogura T, Ando M, Miyazawa H, Tanaka T, Saijo Y, Hagiwara K, Morita S, Nukiwa T, North-East Japan Study Group: Gefitinib or chemotherapy for non-small-cell lung cancer with mutated EGFR. N Engl J Med 2010, 362:2380-2388.
28. Mitsudomi T, Morita S, Yatabe Y, Negoro S, Okamoto I, Tsurutani J, Seto T, Satouchi M, Tada H, Hirashima T, Asami K, Katakami N, Takada M, Yoshioka H, Shibata K, Kudoh S, Shimizu E, Saito H, Toyooka S, Nakagawa K, Fukuoka M, West Japan Oncology Group: Gefitinib versus cisplatin plus docetaxel in patients with non-smallcell lung cancer harbouring mutations of the epidermal growth factor receptor (WJTOG3405): An open label, randomised phase 3 trial. Lancet Oncol 2010, 11:121-128.

29. Rosell R, Carcereny E, Gervais R, Vergnenegre A, Massuti B, Felip E, Palmero R, Garcia-Gomez R, Pallares C, Sanchez JM, Porta R, Cobo M, Garrido P, Longo F, Moran T, Insa A, De Marinis F, Corre R, Bover I, Illiano A, Dansin E, De Castro J, Milella M, Reguart N, Altavilla G, Jimenez U, Provencio M, Moreno MA, Terrasa J, Muñoz-Langa J, et al: Erlotinib versus standard chemotherapy as first-line treatment for European patients with advanced EGFR mutation-positive non-small-cell lung cancer(EURTAC): A multicentre, open-label, randomized phase 3 trial. Lancet Oncol 2012, 13:239-246.

30. Kwak EL, Bang YJ, Camidge DR, Shaw AT, Solomon B, Maki RG, Ou SH, Dezube BJ, Jänne PA, Costa DB, Varella-Garcia M, Kim WH, Lynch TJ, Fidias P, Stubbs H, Engelman JA, Sequist LV, Tan W, Gandhi L, Mino-Kenudson M, Wei GC, Shreeve SM, Ratain MJ, Settleman J, Christensen JG, Haber DA Wilner K, Salgia R, Shapiro Gl, Clark JW, et al: Anaplastic lymphoma kinase inhibition in non-small-cell lung cancer. N Engl J Med 2010, 363:1693-1703.

31. Dutt A, Ramos AH, Hammerman PS, Mermel C, Cho J, Sharifnia T, Chande A, Tanaka KE, Stransky N, Greulich H, Gray NS, Meyerson M: Inhibitor-sensitive FGFR1 amplification in human non-small cell lung cancer. PLoS One 2011, 6:e20351.

32. Hammerman PS, Sos ML, Ramos AH, Xu C, Dutt A, Zhou W, Brace LE, Woods BA, Lin W, Zhang J, Deng X, Lim SM, Heynck S, Peifer M, Simard JR, Lawrence MS, Onofrio RC, Salvesen HB, Seidel D, Zander T, Heuckmann JM, Soltermann A, Moch H, Koker M, Leenders F, Gabler F, Querings S, Ansén S, Brambilla E, Brambilla C, et al: Mutations in the DDR2 kinase gene identify a novel therapeutic target in squamous cell lung cancer. Cancer Discov 2011, 1:78-89.

33. Kayser K, Fritz P, Drlicek M, Rahn W: Expert consultation by use of telepathology-the Heidelberg experiences. Anal Cell Pathol 1995, 9:53-60.

doi:10.1186/1746-1596-9-103

Cite this article as: Yamagishi et al:: Histological comparison between preoperative and surgical specimens of non-small cell lung cancer for distinguishing between "squamous" and "non-squamous" cell carcinoma. Diagnostic Pathology 2014 9:103.

\section{Submit your next manuscript to BioMed Central and take full advantage of:}

- Convenient online submission

- Thorough peer review

- No space constraints or color figure charges

- Immediate publication on acceptance

- Inclusion in PubMed, CAS, Scopus and Google Scholar

- Research which is freely available for redistribution 